\author{
Anna H. Jankowiak \\ Uniwersytet Ekonomiczny we Wrocławiu \\ e-mail: anna.jankowiak@ue.wroc.pl
}

\title{
ROLA JAPONII W REGIONIE AZJI I PACYFIKU - HANDEL ZAGRANICZNY ORAZ BEZPOŚREDNIE INWESTYCJE ZAGRANICZNE
}

\section{THE ROLE OF JAPAN IN THE ASIA \\ AND PACIFIC REGION - INTERNATIONAL TRADE AND FOREIGN DIRECT INVESTMENT}

DOI: $10.15611 / \mathrm{e} .21 .2016 .1 .03$

JEL Classification: I310, O100

Streszczenie: Japonia jako jeden z wysoko rozwiniętych krajów świata od wielu lat odgrywa znaczącą rolę w regionie Azji i Pacyfiku. To właśnie kraje regionu są rynkiem docelowym dla produktów japońskich i kapitału japońskiego. Poprzez handel zagraniczny oraz bezpośrednie inwestycje zagraniczne Japonia wpływa na kształt relacji w regionie i proces azjatyckiego regionalizmu. Stale ok. 50\% japońskiego eksportu trafia do państw azjatyckich, a podobny procent importu japońskiego pochodzi z badanego regionu. Japonia jest także znaczącym eksporterem kapitału w postaci inwestycji zagranicznych do państw regionu, gdzie trafia ich znaczna część. Handel i inwestycje zagraniczne to tylko część wskaźników świadczących o roli Japonii w regionalizmie Azji i Pacyfiku, lecz są to czynniki wyraźnie wskazujące na duże zaangażowanie Japonii w regionie. Celem artykułu jest przedstawienie roli, jaką odgrywa Japonia w procesach regionalizmu azjatyckiego. Cel ten zostanie zrealizowany przez analizę japońskiego handlu zagranicznego i strumieni napływu i odpływu bezpośrednich inwestycji zagranicznych.

Słowa kluczowe: regionalizm w regionie Azji i Pacyfiku, Japonia, handel zagraniczny, bezpośrednie inwestycje zagraniczne.

Summary: Japan as one of highly developed countries of the world, for many years, plays a significant role in the Asia-Pacific region. Countries of the region are the target market for Japanese products and Japanese capital. Through the foreign trade and foreign direct investment, Japan affects the shape of the relationship in the region and the process of Asian regionalism. Constantly around $50 \%$ of Japanese exports go to Asian countries and a similar percentage of Japanese imports come from the examined region. Japan is also a major exporter of capital in the form of foreign investment to countries in the region, which makes up a considerable part of it. Trade and foreign investment are the only part of the indicators of the role of Japan in the Asia-Pacific regionalism, but these are factors clearly indicating the strong commitment of Japan in the region. The aim of the article is to present the role played 
by Japan in the Asian regionalism, by showing the Japanese foreign trade and inflows and outflows of foreign direct investment.

Keywords: regionalism in the Asian and pacific region, Japan, international trade, foreign direct investment.

\section{Wstęp}

Jednym z państw regionu Azji i Pacyfiku, które aspiruje do objęcia pozycji lidera w procesie regionalizmu azjatyckiego, jest niewątpliwie Japonia. Japonia pozostaje dominującym podmiotem $\mathrm{w}$ badanym regionie, a przyczyn tego stanu rzeczy można upatrywać w czynnikach historycznych, ekonomicznych i politycznych. Priorytety i kierunki zagranicznej polityki ekonomicznej Japonii charakteryzują się dużą stabilnością, przy niewielkich korektach, będących pochodną zmian sytuacji wewnętrznej i międzynarodowej oraz aspiracji do odgrywania większej roli w świecie. Stałym elementem tej polityki jest ochrona interesów gospodarczych, która wraz z zapewnieniem bezpieczeństwa zewnętrznego zajmuje czołowe miejsce w określaniu japońskiej racji stanu.

Istotne miejsce spraw gospodarczych w polityce rządu wiąże się, $\mathrm{z}$ jednej strony, z szybkim rozwojem ekonomicznym, z drugiej zaś, ze specyfiką tego kraju ubogiego $\mathrm{w}$ surowce, pokrywającego $\mathrm{w}$ tej dziedzinie $85 \%$ swego zapotrzebowania importem, głównie z państw Azji i Pacyfiku. Region ten jest dla Japonii obszarem strategicznym z punktu widzenia jej interesów gospodarczych. Jednocześnie obserwacja jej rynków eksportowych wskazuje, że 50\% swoich towarów Japonia lokuje właśnie w tym regionie. Ważną rolę odgrywa bliskość geograficzna, dobra znajomość krajów tego obszaru, interesy gospodarcze oraz dążenie do tworzenia przyjaznego otoczenia, sprzyjającego jej rozwojowi1. Ścisły związek Japonii z regionem Azji i Pacyfiku jest widoczny także przez zaangażowanie japońskich kapitałów w postaci pomocy rozwojowej (Official Development Aid), która w znacznej większości trafia do państw badanego regionu. Przekazywanie kapitału w postaci ODA służy budowaniu infrastruktury i potencjału ekonomicznego państw regionu, co w długim okresie przekłada się na zwiększenie strumienia japońskiego handlu zagranicznego $i$ inwestycji zagranicznych ${ }^{2}$.

Celem artykułu jest przedstawienie roli Japonii w regionie i w procesach regionalizmu Azji i Pacyfiku. Analizie zostanie poddany handel zagraniczny badanego kraju oraz strumień odpływu i napływu kapitału w postaci bezpośrednich inwestycji zagranicznych. Metodą zastosowaną w artykule jest metoda analizy statystycznej, oparta głównie na danych japońskiego JETRO.

\footnotetext{
Więcej na ten temat w [Drelich-Skulska (red.) 2007].
}

2 Więcej na temat w [Jankowiak 2015, s. 106-116]. 


\section{Wymiana handlowa Japonii z państwami regionu}

W XXI wieku, po perturbacjach spowodowanych kryzysem azjatyckim, badany kraj podtrzymał dobrą passę w wymianie handlowej z państwami Azji i Pacyfiku. Na rynkach tego regionu lokowano w latach 2000-2005 przeciętnie 45\% japońskiego eksportu, obserwując tendencję wzrostową. Drugim partnerem pozostawały Stany Zjednoczone $\mathrm{z}$ udziałem oscylującym na poziomie $25 \% \mathrm{z}$ trendem malejącym. Natomiast trzecim regionem, który odbierał japońskie towary, była Unia Europejska z udziałem 15\%. W latach 2000-2005 amerykański udział w japońskim rynku spadł z poziomu 19\% do 12,4\% [Statistical Handbook...], co jeszcze bardziej skomplikowało wzajemne stosunki gospodarcze. Dominującą pozycję w japońskim imporcie w tym okresie zajmowali partnerzy z Azji ze średniorocznym udziałem 44\%, na drugim miejscu uplasowały się państwa ze Środkowego Wschodu z rosnącym udziałem, który ustabilizował się na poziomie 17\% w 2005 roku, i zdeklasowały one USA, które spadły na pozycje trzecią.

Tabela 1. Eksport Japonii do wybranych regionów świata w latach 2009-2013

\begin{tabular}{|l|c|c|r|r|r|r|r|r|r|r|}
\hline \multirow{3}{*}{ Region } & \multicolumn{2}{|c|}{2009} & \multicolumn{2}{c|}{2010} & \multicolumn{2}{c|}{2011} & \multicolumn{2}{c|}{2012} & \multicolumn{2}{|c|}{2013} \\
\cline { 2 - 12 } & $\begin{array}{c}\text { mld } \\
\text { USD }\end{array}$ & $\%$ & $\begin{array}{c}\text { mld } \\
\text { USD }\end{array}$ & $\%$ & $\begin{array}{c}\text { mld } \\
\text { USD }\end{array}$ & $\%$ & $\begin{array}{c}\text { mld } \\
\text { USD }\end{array}$ & $\%$ & $\begin{array}{c}\text { mld } \\
\text { USD }\end{array}$ & $\%$ \\
\hline Lącznie & $\mathbf{5 8 0 , 7 9}$ & $\mathbf{1 0 0 , 0}$ & $\mathbf{7 6 7 , 0 3}$ & $\mathbf{1 0 0 , 0}$ & $\mathbf{8 2 0 , 7 9}$ & $\mathbf{1 0 0 , 0}$ & $\mathbf{8 0 1 , 3 3}$ & $\mathbf{1 0 0 , 0}$ & $\mathbf{7 1 9 , 2 0}$ & $\mathbf{1 0 0 , 0}$ \\
\hline Azja & 314,41 & 54,1 & 430,50 & 56,1 & 459,08 & 55,9 & 438,10 & 54,7 & 390,14 & 54,3 \\
\hline USA & 93,65 & 16,1 & 118,20 & 15,4 & 125,67 & 15,3 & 140,62 & 17,6 & 133,20 & 18,5 \\
\hline Europa & 72,37 & 12,5 & 86,73 & 11,3 & 95,41 & 11,6 & 81,74 & 10,2 & 72,17 & 10,0 \\
\hline $\begin{array}{l}\text { Ameryka } \\
\text { Centralna } \\
\text { i Południowa }\end{array}$ & 33,12 & 5,7 & 43,97 & 5,7 & 44,10 & 5,4 & 43,21 & 5,4 & 36,80 & 5,1 \\
\hline Oceania & 15,13 & 2,6 & 20,36 & 2,7 & 22,33 & 2,7 & 23,08 & 2,9 & 20,92 & 2,9 \\
\hline $\begin{array}{l}\text { Rosja } \\
\text { i kraje WNP }\end{array}$ & 4,13 & 0,7 & 9,16 & 1,2 & 13,73 & 1,7 & 14,64 & 1,8 & 13,17 & 1,8 \\
\hline $\begin{array}{l}\text { Środkowy } \\
\text { Wschód }\end{array}$ & 21,65 & 3,7 & 25,18 & 3,3 & 24,53 & 3,0 & 28,43 & 3,6 & 25,53 & 3,6 \\
\hline Afryka & 9,50 & 1,6 & 12,00 & 1,6 & 13,17 & 1,6 & 12,97 & 1,6 & 11,53 & 1,6 \\
\hline
\end{tabular}

Źródło: opracowanie własne na podstawie danych [JETRO].

W latach 2009-2013 region Azji i Pacyfiku (zob. tab. 1) nadal odgrywał znaczącą rolę w handlu zagranicznym Japonii. W szczytowym roku 2010 56,1\% japońskiego eksportu trafiało do państw azjatyckich, natomiast w ostatnim zbadanym roku, tj. 2013, udział ten nieco zmalał i stanowił 54,3\% całości eksportu. Dominacja jednego regionu w japońskiej sprzedaży zagranicznej jest wyraźnie odczuwalna, co przekłada się również na postrzeganie Japonii jako siły kształtującej procesy ekonomiczne w badanym regionie. Podobnie jak we wcześniejszych okresach drugim po krajach Azji odbiorcą dla japońskiego eksportu były Stany Zjednoczone (z udziałem 
na poziomie 18,5\%), trzecim natomiast kraje Unii Europejskiej (z 10-procentowym udziałem).

Poddając analizie japoński import (zob. tab. 2), należy zauważyć dwie ciekawe tendencje. Niewątpliwie największym dostawcą towarów na japoński rynek są kraje azjatyckie, co wzmacnia prezentowaną wyżej opinię o nierozerwalności relacji Japonii z regionem azjatyckim oraz o dominującej roli tego kraju w regionalizmie. Import z krajów azjatyckich w stosunku do całego importu Japonii przekroczył 44\% i jest to wartość podobna w latach 2009-2013. Pierwsze zmiany można zaobserwować w wielkości importu ze Stanów Zjednoczonych, który wykazuje tendencję spadkową. Na początku XXI wieku 19\% importu japońskiego stanowiły towary amerykańskie, w 2009 r. było to już 11\%, podczas gdy w 2013 r. było to nieco ponad 8\%. Należy zatem stwierdzić, że stale na rynek japoński trafia mniej towarów "made in USA". Drugim zjawiskiem godnym uwagi jest dynamicznie wzrastający udział importu z krajów Środkowego Wschodu, w którym dominują przede wszystkim Arabia Saudyjska, Zjednoczone Emiraty Arabskie oraz Katar. W 2013 r. ponad $19 \%$ wszystkich towarów trafiających na rynek japoński stanowiły towary z regionu Środkowego Wschodu.

Tabela 2. Import Japonii z wybranych regionów świata w latach 2009-2013

\begin{tabular}{|l|r|r|r|r|r|r|r|r|r|r|}
\hline \multirow{2}{*}{ Region } & \multicolumn{2}{|c|}{2009} & \multicolumn{2}{|c|}{2010} & \multicolumn{2}{c|}{2011} & \multicolumn{2}{|c|}{2012} & \multicolumn{2}{|c|}{2013} \\
\cline { 2 - 12 } & $\begin{array}{c}\text { mld } \\
\text { USD }\end{array}$ & $\%$ & $\begin{array}{c}\text { mld } \\
\text { USD }\end{array}$ & $\%$ & $\begin{array}{c}\text { mld } \\
\text { USD }\end{array}$ & $\%$ & $\begin{array}{c}\text { mld } \\
\text { USD }\end{array}$ & $\%$ & $\begin{array}{c}\text { mld } \\
\text { USD }\end{array}$ & $\%$ \\
\hline Lącznie & $\mathbf{5 5 2 , 2 5}$ & $\mathbf{1 0 0}$ & $\mathbf{6 9 1 , 4 5}$ & $\mathbf{1 0 0}$ & $\mathbf{8 5 3 , 0 7}$ & $\mathbf{1 0 0}$ & $\mathbf{8 8 8 , 5 8}$ & $\mathbf{1 0 0}$ & $\mathbf{8 3 8 , 8 9}$ & $\mathbf{1 0 0}$ \\
\hline Azja & 246,43 & 44,6 & 313,18 & 45,3 & 380,67 & 44,6 & 393,57 & 44,3 & 371,35 & 44,3 \\
\hline USA & 59,04 & 10,7 & 67,17 & 9,7 & 74,23 & 8,7 & 76,46 & 8,6 & 70,32 & 8,4 \\
\hline Europa & 59,13 & 10,7 & 66,19 & 9,6 & 80,29 & 9,4 & 83,52 & 9,4 & 78,99 & 9,4 \\
\hline $\begin{array}{l}\text { Ameryka } \\
\begin{array}{l}\text { Centralna i } \\
\text { Południowa }\end{array}\end{array}$ & 20,16 & 3,7 & 28,36 & 4,1 & 34,70 & 4,1 & 35,47 & 4,0 & 34,05 & 4,1 \\
\hline Oceania & 37,99 & 6,9 & 49,31 & 7,1 & 61,34 & 7,2 & 61,64 & 6,9 & 55,47 & 6,6 \\
\hline $\begin{array}{l}\text { Rosja i } \\
\text { kraje WNP }\end{array}$ & 9,66 & 1,8 & 17,17 & 2,5 & 20,01 & 2,4 & 22,10 & 2,5 & 25,03 & 3,0 \\
\hline $\begin{array}{l}\text { Środkowy } \\
\text { Wschód }\end{array}$ & 92,85 & 16,8 & 118,01 & 17,1 & 160,69 & 18,8 & 170,14 & 19,2 & 161,98 & 19,3 \\
\hline Afryka & 9,11 & 1,7 & 11,75 & 1,7 & 17,16 & 2,0 & 21,31 & 2,4 & 19,32 & 2,3 \\
\hline
\end{tabular}

Źródło: opracowanie własne na podstawie danych [JETRO].

Największy wzrost importu odnotowano między latami 2010-2011, kiedy zakupy z zagranicy zwiększono o ponad $23 \%$. W ciągu lat import Japonii wykazywał tendencje wzrostową, choć należy odnotować korektę w 2013 r., gdy zmniejszył się o 5,7\% w stosunku rok do roku. Głównymi dostawcami towarów na rynek japoński, 
obok niekwestionowanego lidera, jakim były Chiny, były także Stany Zjednoczone, Australia, Arabia Saudyjska, Katar i Republika Korei.

Tabela 3. Handel zagraniczny Japonii z państwami azjatyckimi w $2013 \mathrm{r}$.

\begin{tabular}{|c|c|c|c|c|c|c|c|}
\hline \multirow[b]{2}{*}{ Kraj/region } & \multicolumn{3}{|c|}{2013} & \multicolumn{2}{|c|}{$\begin{array}{c}\text { Zmiana rok do } \\
\text { roku \% }\end{array}$} & \multicolumn{2}{|c|}{ Udział } \\
\hline & $\begin{array}{l}\text { eksport } \\
\text { w mld } \\
\text { USD }\end{array}$ & $\begin{array}{l}\text { import } \\
\text { w mld } \\
\text { USD }\end{array}$ & $\begin{array}{l}\text { bilans } \\
\text { w mld } \\
\text { USD }\end{array}$ & eksport & import & eksport & import \\
\hline Świat lącznie & 719,20 & 838,89 & $-119,68$ & $-10,3$ & $-5,6$ & 100,0 & 100,0 \\
\hline Azja & 390,14 & 371,35 & 18,79 & $-11,0$ & $-5,7$ & 54,3 & 44,3 \\
\hline Azja Wschodnia & 377,87 & 362,46 & 15,41 & $-10,8$ & $-5,8$ & 52,5 & 43,2 \\
\hline ASEAN & 111,67 & 118,64 & $-6,97$ & $-14,0$ & $-8,5$ & 15,5 & 14,1 \\
\hline $\begin{array}{l}\text { Azjatyckie gospodarl } \\
\text { nowo uprzemysło- } \\
\text { wione }\end{array}$ & 157,45 & 69,15 & 88,30 & $-8,7$ & $-8,0$ & 21,9 & 8,2 \\
\hline Chiny & 129,85 & 182,19 & $-52,34$ & $-10,3$ & $-3,6$ & 18,1 & 21,7 \\
\hline Hongkong (Chiny) & 37,58 & 1,62 & 35,96 & $-8,8$ & 5,8 & 5,2 & 0,2 \\
\hline Tajwan (Chiny) & 41,88 & 23,88 & 18,01 & $-9,3$ & $-1,1$ & 5,8 & 2,9 \\
\hline Korea Południowa & 56,88 & 36,13 & 20,75 & $-7,9$ & $-11,1$ & 7,9 & 4,3 \\
\hline Singapur & 21,10 & 7,52 & 13,58 & $-9,7$ & $-14,5$ & 2,9 & 0,9 \\
\hline Tajlandia & 36,22 & 22,19 & 14,03 & $-17,4$ & $-6,4$ & 5,0 & 2,7 \\
\hline Malezja & 15,33 & 30,01 & $-14,67$ & $-13,7$ & $-9,0$ & 2,1 & 3,6 \\
\hline Indonezja & 17,14 & 29,08 & $-11,94$ & $-15,7$ & $-10,2$ & 2,4 & 3,5 \\
\hline Filipiny & 9,74 & 9,28 & 0,47 & $-18,1$ & $-1,1$ & 1,4 & 1,1 \\
\hline Brunei & 0,15 & 4,80 & $-4,65$ & $-18,9$ & $-20,1$ & 0,0 & 0,6 \\
\hline Wietnam & 10,59 & 14,31 & $-3,72$ & $-1,7$ & $-5,5$ & 1,5 & 1,7 \\
\hline Laos & 0,12 & 0,11 & 0,01 & $-11,4$ & $-12,5$ & 0,0 & 0,0 \\
\hline Myanmar & 1,06 & 0,76 & 0,30 & $-15,9$ & 12,8 & 0,2 & 0,1 \\
\hline Kambodża & 0,21 & 0,59 & $-0,38$ & $-10,3$ & 44,4 & 0,0 & 0,1 \\
\hline Indie & 8,67 & 7,14 & 1,53 & $-18,4$ & 1,8 & 1,2 & 0,9 \\
\hline Pakistan & 1,43 & 0,48 & 0,95 & $-15,8$ & 11,0 & 0,2 & 0,1 \\
\hline Bangladesz & 0,88 & 0,90 & $-0,02$ & $-10,9$ & 24,2 & 0,1 & 0,1 \\
\hline Sri Lanka & 0,58 & 0,30 & 0,28 & 28,0 & 7,6 & 0,1 & 0,0 \\
\hline Mongolia & 0,30 & 0,02 & 0,28 & $-13,1$ & $-24,8$ & 0,0 & 0,0 \\
\hline Macao & 0,30 & 0,03 & 0,27 & 13,3 & $-8,9$ & 0,0 & 0,0 \\
\hline
\end{tabular}

Źródło: opracowanie własne na podstawie danych [JETRO].

Najbardziej znaczącym partnerem zagranicznym dla japońskiej gospodarki są Chiny, które są zarówno największym dostawcą towarów na rynek japoński, jak i odbiorcą wyrobów japońskich (zob. tab. 3). W 2013 r. import z Chin stanowił prawie $22 \%$ całości zakupów zagranicznych, natomiast eksport do Państwa Środka przekroczył 18\% [JETRO]. Dane te pokazują, że dominujący gospodarczo partner Japonii ulokowany jest właśnie w regionie Azji i Pacyfiku, co pogłębia regionalizm w japońskiej polityce ekonomicznej. Głównymi odbiorcami japońskich towarów 
była także Korea Południowa - z prawie 8-procentowym udziałem, oraz Hongkong, Tajwan i Tajlandia, których udziały przekraczały 5\%. W imporcie na rynek japoński, oprócz Chin, głównym partnerem była także Korea Południowa (4,3\% całego importu) i - co warto zauważyć - również dwa kraje rozwijające się, czyli Malezja i Indonezja, których udziały kształtowały się na poziomie 3,6 i 3,5\%.

Zasadniczo region azjatycki dominuje w strukturze handlu zagranicznego Japonii. Jak zauważono wcześniej, zarówno w eksporcie, jak i w imporcie współpraca z państwami regionu jest znacząca dla funkcjonowania gospodarki japońskiej. Doprecyzowując, należy zauważyć, że w geograficznym rozłożeniu partnerów w handlu zagranicznym Japonii region Azji Wschodniej zajmuje kluczową pozycję, gdyż w 2013 r. tylko 1,8\% eksportu dokonanego do państw azjatyckich trafiło poza Azję Wschodnią, a w przypadku importu było to zaledwie 1,1\% [JETRO].

Wpływ na strumień handlu zagranicznego Japonii mają umowy o wolnym handlu zawierane z państwami regionu, które stanowią ułatwienie dla firm w przepływach towarowych. Władze japońskie przez wiele lat nie przejawiały zainteresowania tworzeniem umów o wolnym handlu [Yoshida 2004, s. 19], lecz od początku XXI wieku Japonia stara się umacniać swoją pozycję ekonomiczną i polityczną w badanym regionie właśnie przez zawieranie regionalnych porozumień handlowych (Regional Trade Agreements - RTAs). Większość porozumień ma charakter dwustronnych umów o wolnym handlu (Free Trade Agreements - FTAs), stąd też należy wskazać bilateralizm jako dominujący obecnie sposób kształtowania międzynarodowej polityki handlowej przez Japonię. Przewaga umów bilateralnych jest także konsekwencją braku Aktu Końcowego Rundy Doha Światowej Organizacji Handlu. Dwustronny charakter porozumień zawieranych w badanym regionie może powodować niekorzystny dla światowego handlu efekt przesunięcia handlu. Początkiem procesu tworzenia RTAs była umowa między Japonią a Singapurem podpisana w 2002 r., która stała się początkiem japońskich działań mających na celu zawarcie FTA z pozostałymi państwami regionu. Umowy o wolnym handlu są niezwykle istotne z punktu widzenia japońskich interesów. Władze japońskie prowadzą politykę zawierania tego typu umowy z każdym ważnym partnerem handlowym z regionu, w tym także z krajami rozwijającymi się, dysponującymi chłonnym rynkiem zbytu dla japońskich towarów. Według stanu na październik 2014 r., Japonia była stroną w 14 umowach typu EPA (Economic Partnership Agreement) oraz FTA (Free Trade Agreement). W przypadku 9 umów ich warunki były dopiero negocjowane lub z różnych przyczyn były one przesuwane w czasie [Free Trade Agreement (FTA) ...]. 


\section{Przepływy kapitałowe w postaci bezpośrednich inwestycji zagranicznych Japonii}

Transfer kapitału pomiędzy krajami regionu w postaci bezpośrednich inwestycji zagranicznych jest postrzegany jako czynnik stymulujący rozwój gospodarczy azjatyckich krajów rozwijających się oraz lokalną produkcję przemysłową. Przedsiębiorstwa japońskie, chcąc poprawić własną konkurencyjność, zdecydowały się już w latach 80 . XX wieku przenieść swoje oddziały produkcyjne do rozwijających się krajów badanego regionu [Okamato 1997, s. 10], stąd też pozycję oraz rolę Japonii w azjatyckim regionalizmie można postrzegać przez pryzmat nie tylko wymiany handlowej z regionem, lecz także strumienia kapitału zainwestowanego przez rodzime przedsiębiorstwa $\mathrm{w}$ pozostałych krajach regionu oraz wielkości napływu obcego kapitału do Japonii. W XXI wieku Japonia aktywnie promuje wymianę handlową ze wszystkimi partnerami z regionu Azji i Pacyfiku, co przejawia się w podejmowaniu intensywnych wewnętrznych działań marketingowych i legislacyjnych, których celem jest liberalizacja przepływów kapitałowych. Globalizacja stosunków gospodarczych oraz skuteczne działania podejmowane przez japońskich przywódców wpłynęły na intensyfikację przepływów kapitałowych w regionie Azji i Pacyfiku oraz umocniły pozycję Japonii w procesach regionalizmu azjatyckiego.

W latach 2009-2013 wartość bezpośrednich inwestycji zagranicznych ulokowanych przez Japonię na świecie wzrosła o 80\% i w 2013 r. wyniosła 135 mld USD [JETRO] (zob. tab. 4). Spowolnienie w gospodarce światowej miało swoje wyraźne odzwierciedlenie w strumieniu napływu w badanych latach japońskich inwestycji do krajów goszczących. Głównymi kierunkami ekspansji inwestorów japońskich były Europa, USA oraz kraje azjatyckie. Jeszcze kilka lat temu w strukturze inwestycji japońskich dominowały USA i Europa, gdzie poprzez inwestycje na tych rynkach japońskie firmy przełamywały bariery w dostępie do tych rynków. Równocześnie przez tworzenie wspólnych firm z kapitałem z tych regionów wzmacniały konkurencyjność japońskich korporacji na innych rynkach i ułatwiały szybsze absorbowanie nowych rozwiązań technologicznych. W badanym okresie szczytową wartość japońskich inwestycji ulokowanych w Europie odnotowano w 2011 r. (39,84 mld USD), natomiast w 2013 r. do Europy trafiło ponad 32 mld USD. W tym samym roku japońskie firmy zainwestowały w USA prawie 44 mld USD. Z analizowanych danych wynika, że aktualnie także region azjatycki jest coraz ważniejszym odbiorcą kapitału japońskiego.

W latach 2009-2013 odnotować można ponad 96-procentowy wzrost wartości japońskich inwestycji w krajach azjatyckich, a w samym tylko roku 2013 do regionu trafiło ponad 40 mld USD, czyniąc Azję drugim rynkiem dla przedsiębiorstw japońskich. Warto zauważyć, że rosnąca aktywność inwestycyjna Japonii w tym regionie jest zgodna z kierunkami prowadzonej przez nią polityki zagranicznej, 
w której od wielu dziesięcioleci podkreśla się dążenie tego kraju do zbudowania silnego azjatyckiego bloku ekonomicznego z Japonią jako liderem.

Tabela 4. Odpływ japońskich bezpośrednich inwestycji zagranicznych w latach 2009-2013 (w mld USD)

\begin{tabular}{|l|r|r|r|r|r|}
\hline & 2009 & 2010 & 2011 & 2012 & 2013 \\
\hline Łącznie & 74,65 & 57,22 & 108,81 & 122,36 & 135,05 \\
\hline Azja & 20,64 & 22,13 & 39,49 & 33,48 & 40,47 \\
\hline USA & 10,66 & 9,19 & 14,73 & 31,97 & 43,70 \\
\hline Europa & 17,83 & 15,04 & 39,84 & 31,02 & 32,23 \\
\hline $\begin{array}{l}\text { Ameryka } \\
\text { Centralna } \\
\text { i Południowa }\end{array}$ & 17,39 & & & & \\
\hline Oceania & 7,63 & 6,35 & 11,29 & 10,45 & 10,20 \\
\hline Rosja & 0,39 & 0,35 & 8,77 & 11,07 & 6,10 \\
\hline $\begin{array}{l}\text { Środkowy } \\
\text { Wschód }\end{array}$ & 0,58 & $-0,35$ & 0,34 & 0,76 & 0,45 \\
\hline Afryka & $-0,30$ & $-0,37$ & 0,46 & 0,45 & 0,09 \\
\hline
\end{tabular}

Źródło: opracowanie własne na podstawie danych [JETRO].

Analizując szczegółowo kierunki japońskich inwestycji zagranicznych dokonywanych w krajach azjatyckich (zob. tab. 5), należy stwierdzić, że w latach 2009-2013 największym odbiorcą japońskiego kapitału były kraje ASEAN, do których w $2013 \mathrm{r}$. trafiło ponad 23 mld USD. Wśród krajów ASEAN dominującym miejscem japońskich inwestycji bezpośrednich była Tajlandia (ponad 10 mld USD, co stanowiło ponad osiemnastokrotny wzrost w stosunku do roku poprzedniego), która w $2013 \mathrm{r}$. wyprzedziła nawet Chiny, do których trafił kapitał w wysokości 9,1 mld USD. Choć można odnotować znaczący spadek odpływu japońskiego kapitału do wybranych krajów (np. Chiny), to należy jednocześnie zauważyć, że w innych krajach regionu strumień napływu kapitału japońskiego zwiększył się. Można zatem założyć, że w zależności od potrzeb i wskaźników ekonomicznych kapitał japoński jest inwestowany w różnych krajach, lecz nadal pozostaje w regionie azjatyckim. Reorientacja ekspansji japońskich inwestorów na rynki Azji i Pacyfiku jest wynikiem polityki ekonomicznej konsekwentnie prowadzonej przez kolejne rządy Kraju Kwitnącej Wiśni, które dążyły do zbudowania w tym regionie trwałych i wielopłaszczyznowych powiązań gospodarczych oraz kapitałowych w celu umocnienia swojej pozycji ekonomicznej i politycznej. Ważnym zjawiskiem wpływającym na zmianę kierunków inwestycji japońskich jest globalizacja międzynarodowych stosunków gospodarczych, która w regionie Azji i Pacyfiku przejawia się intensyfikacją procesów integracyjnych oraz rosnącą aktywnością japońskich korporacji. 
Tabela 5. Japońskie inwestycje zagraniczne w wybranych krajach azjatyckich w latach 2009-2013 (w mld USD)

\begin{tabular}{|l|r|r|r|r|r|}
\hline & 2009 & 2010 & 2011 & 2012 & \multicolumn{1}{c|}{2013} \\
\hline Azja & 20,64 & 22,13 & 39,49 & 33,48 & 40,47 \\
\hline Chiny & 6,90 & 7,25 & 12,65 & 13,48 & 9,10 \\
\hline $\begin{array}{l}\text { Azjatyckie gospodarki } \\
\text { nowo uprzemysłowione }\end{array}$ & 5,91 & 6,90 & 9,30 & 8,04 & 8,96 \\
\hline • Hongkong (Chiny) & 1,61 & 2,09 & 1,51 & 2,36 & 1,79 \\
\hline • Tajwan (Chiny) & 0,34 & $-0,11$ & 0,86 & 0,12 & 0,33 \\
\hline - Korea Południowa & 1,08 & 1,09 & 2,44 & 4,00 & 3,30 \\
\hline • Singapur & 2,88 & 3,85 & 4,49 & 1,57 & 3,55 \\
\hline ASEAN & 7,00 & 8,93 & 19,65 & 10,68 & 23,62 \\
\hline ASEAN4 & 3,54 & 4,31 & 13,20 & 6,40 & 16,59 \\
\hline - Tajlandia & 1,63 & 2,25 & 7,13 & 0,55 & 10,17 \\
\hline - Indonezja & 0,48 & 0,49 & 3,61 & 3,81 & 3,91 \\
\hline • Malezja & 0,62 & 1,06 & 1,44 & 1,31 & 1,27 \\
\hline • Filipiny & 0,81 & 0,51 & 1,02 & 0,73 & 1,24 \\
\hline Wietnam & 0,56 & 0,75 & 1,86 & 2,57 & 3,27 \\
\hline Indie & 3,66 & 2,86 & 2,33 & 2,80 & 2,16 \\
\hline
\end{tabular}

Źródło: opracowanie własne na podstawie danych [JETRO].

Spowolnienie gospodarki światowej zapoczątkowane w 2008 r. miało swoje silne odzwierciedlenie w strumieniu napływu BIZ do Japonii. Nie jest to zjawisko nietypowe, bowiem koniunktura na rynku światowym ma swoje przełożenie w strukturze światowych bezpośrednich inwestycji zagranicznych. W latach 2009-2013 wartość kapitału zagranicznego lokowanego w Japonii zmniejszyła się o 80\% i w 2013 r. wyniosła 2,36 mld USD (zob. tab. 6) [JETRO]. Wśród największych inwestorów stałe miejsce utrzymują Stany Zjednoczone, które w 2013 r. zainwestowały w Japonii 1,38 mld USD. Drugim co do wielkości inwestorem w Japonii były kraje europejskie (1,06 mld USD w 2013 r.), trzecie miejsce w badanym roku, z kapitałem prawie $900 \mathrm{mln}$ USD, zajęły kraje azjatyckie. Analiza danych zawartych w tab. 6 pozwala na wniosek, że nie ma jednego dominującego regionu, który systematycznie inwestuje najwięcej kapitału w gospodarce japońskiej. Stany Zjednoczone, na przemian z Europą, dominują w strukturze BIZ w Japonii, lecz jednocześnie nie można stwierdzić, że poziom tych inwestycji jest ustabilizowany. Podobne wnioski można wyciągnąć z badania inwestycji z krajów azjatyckich, które charakteryzują się dużymi dysproporcjami. 
Tabela 6. Napływ bezpośrednich inwestycji zagranicznych do Japonii w latach 2009-2013 (w mld USD)

\begin{tabular}{|l|r|r|r|r|r|}
\hline & 2009 & 2010 & 2011 & 2012 & 2013 \\
\hline Lącznie & $\mathbf{1 1 , 8 4}$ & $\mathbf{- 1 , 3 6}$ & $-\mathbf{1 , 7 0}$ & $\mathbf{1 , 7 6}$ & $\mathbf{2 , 3 6}$ \\
\hline Azja & 1,09 & 3,13 & 1,38 & 2,90 & 0,87 \\
\hline USA & 1,83 & 2,96 & $-3,20$ & $-0,11$ & 1,38 \\
\hline Europa & 8,21 & 0,20 & 1,20 & 0,89 & 1,06 \\
\hline $\begin{array}{l}\text { Ameryka Central- } \\
\text { na i Południowa }\end{array}$ & 0,69 & $-7,72$ & $-1,39$ & $-1,96$ & $-1,36$ \\
\hline Oceania & 0,05 & $-0,02$ & 0,09 & 0,12 & 0,38 \\
\hline Rosja & 0,00 & - & - & $-0,01$ & 0,01 \\
\hline Środkowy Wschód & 0,02 & $-0,00$ & 0,14 & $-0,12$ & 0,01 \\
\hline Afryka & 0,06 & 0,04 & $-0,01$ & $-0,02$ & $-0,01$ \\
\hline
\end{tabular}

Źródło: opracowanie własne na podstawie danych [JETRO].

Wiele uwag można poczynić na temat wewnętrznej struktury azjatyckich BIZ w Japonii (zob. tab. 7). Głównymi inwestorami pochodzącymi z Azji w latach 2009-2013 były Singapur i kraje należące do ASEAN (oba podmioty dokonały transferu kapitału w 2013 r. w wysokości powyżej 0,3 mld USD). Warto zwrócić także uwagę na inwestycje Korei Południowej, która w poprzednich latach była znaczącym inwestorem na rynku japońskim, lecz dynamika napływu koreańskich BIZ do Japonii mocno osłabła (w latach 2009-2013 inwestycje koreańskie w Japonii zmniejszyły się o 80\%). Chiny, coraz bardziej aktywne w strukturze światowych inwestycji zagranicznych, zainwestowały w Japonii w 2013 r. 0,14 mld USD.

Tabela 7. Bezpośrednie inwestycje zagraniczne z wybranych krajów azjatyckich w Japonii w latach 2009-2013 (w mld USD)

\begin{tabular}{|l|r|r|r|r|r|}
\hline & 2009 & 2010 & 2011 & 2012 & 2013 \\
\hline Azja & 1,09 & 3,13 & 1,38 & 2,90 & 0,87 \\
\hline Chiny & $-0,14$ & 0,31 & 0,11 & 0,07 & 0,14 \\
\hline $\begin{array}{l}\text { Azjatyckie gospodarki } \\
\text { nowo uprzemysłowione }\end{array}$ & 0,99 & 2,57 & 1,21 & 2,77 & 0,73 \\
\hline • Hongkong (Chiny) & $-0,08$ & 0,70 & 0,13 & 0,87 & 0,17 \\
\hline - Tajwan (Chiny) & 0,06 & 0,02 & 0,11 & 0,37 & 0,19 \\
\hline - Korea Południowa & 0,25 & 0,27 & 0,20 & 0,56 & 0,05 \\
\hline - Singapur & 0,76 & 1,57 & 0,78 & 0,98 & 0,33 \\
\hline ASEAN & 0,98 & 1,81 & 0,83 & 1,00 & 0,32 \\
\hline ASEAN4 & 0,23 & 0,23 & 0,05 & 0,02 & $-0,01$ \\
\hline - Tajlandia & 0,02 & 0,01 & $-0,00$ & 0,04 & 0,00 \\
\hline • Indonezja & 0,00 & 0,04 & $-0,00$ & $-0,00$ & $-0,09$ \\
\hline • Malezja & 0,20 & 0,18 & 0,05 & $-0,02$ & 0,07 \\
\hline - Filipiny & - & $-0,00$ & $-0,00$ & 0,00 & 0,01 \\
\hline Indie & 0,01 & 0,00 & 0,01 & 0,02 & 0,02 \\
\hline
\end{tabular}

Źródło: opracowanie własne na podstawie danych [JETRO]. 
Bez względu na opisywany wyżej brak stabilności zarówno w odpływie, jak i napływie BIZ do Japonii należy stwierdzić, że pomimo podejmowanych działań promocyjnych i stosowanych zachęt finansowych, stosunek obcych inwestycji w Japonii do japońskich bezpośrednich inwestycji zagranicznych jest nadal niekorzystny. Według danych japońskiego JETRO, w 2013 r. Japonia dokonała inwestycji na kwotę przekraczającą 135 mld USD, podczas gdy napłynęło do niej tylko nieco ponad 2,3 mld, czyli prawie sześćdziesiąt razy mniej. Obecnie na szeroką skalę prowadzona jest akcja promocyjna pokazująca atrakcyjność inwestycyjną Japonii jako miejsca docelowego dla inwestorów zagranicznych. „Open the Door to Success in Japan" promowane przez JETRO, przy silnym wsparciu aktualnego premiera Japonii - Shinzo Abe, ma zachęcić zagranicznych inwestorów do lokowania inwestycji właśnie w Japonii.

\section{Zakończenie}

Japonia postrzega proces regionalizmu jako pozytywne zjawisko mające przynieść wymierne korzyści ekonomiczne. Rozwój poszczególnych gospodarek w regionie będzie zapewniał bezpieczeństwo japońskich interesów ekonomicznych [Tanaka, Liff 2009, s. 3]. Aktualnie pozycja Japonii w regionie Azji i Pacyfiku jest stosunkowo silna, lecz należy zauważyć niekorzystny trend w gospodarce japońskiej, jakim jest niski stopień wzrostu gospodarczego, kształtujący się obecnie na poziomie 1\%. Jednak należy zwrócić uwagę także na inne zjawisko, które może pozytywnie wpłynąć na stan rozwoju gospodarki japońskiej, jakim jest szybkie tempo rozwoju krajów azjatyckich. To właśnie partnerzy Japonii w handlu i inwestycjach rozwijają się teraz najszybciej. Według prognoz, w 2017 r. Japonia utrzyma wysoką pozycję i stanie się piątym największym eksporterem na świecie z rocznym eksportem ok. 994 mld USD. Największym odbiorcą japońskich towarów pozostaną kraje azjatyckie, a eksport do Chin, Stanów Zjednoczonych i Korei Południowej będzie stanowił 48\% całkowitego eksportu w 2017 r. Podobnie będzie się kształtował import japoński, który, według prognozy, wzrośnie do 1174 mld USD, co uplasuje Japonię na 4. miejscu na świecie (największy wzrost zakładany jest w handlu z Chinami) [ING International Trade Study].

Zarówno handel zagraniczny, jak i inwestycje zagraniczne budują silną pozycję Japonii w regionie Azji i Pacyfiku, lecz należy uwzględnić także aktualny stan zarówno gospodarki japońskiej, jak i innych państw regionu, w tym przede wszystkim Chin. Mimo wielu działań podejmowanych przez premiera Shinzo Abe, stan gospodarki nie jest optymistyczny, choć obserwuje się wzrost eksportu, co może przełożyć się na wzrost gospodarczy. Sytuacja ma swoje odzwierciedlenie nie tylko na rynku wewnętrznym badanego kraju, lecz także w układzie sił w całym regionie. Coraz mocniej aspirujące do roli mocarstwa Chiny zaczynają dyktować swoje warunki, pozostawiając niejednokrotnie Japonię poza centrum swojego zainteresowania. Mowa tutaj o kolejnych projektach tzw. mega FTA, które swoim zasięgiem 
obejmują różne kombinacje krajów i nie zawsze Japonia jest częścią z nich. Pozycja Japonii w regionalizmie azjatyckim jest bezsprzeczna, lecz w obecnych warunkach gospodarki globalnej działania podejmowane przez premiera Abe, a szczególnie tempo ich wdrażania, mogą wydawać się niewystarczające w obliczu hegemonicznych dążeń Chin do objęcia kontroli nad procesami zachodzącymi w regionie.

\section{Literatura}

Drelich-Skulska B. (red.), 2007, Azja - Pacyfik. Obraz gospodarczy regionu, Wyd. Akademii Ekonomicznej we Wrocławiu, Wrocław.

Free Trade Agreement (FTA) and Economic Partnership Agreement (EPA), Ministry of Foreign Affairs of Japan, http://www.mofa.go.jp/policy/economy/fta/.

ING International Trade Study, Developments in global trade: from 1995 to 2017, Japan, http://www. ingtrade.com/en/home.

Jankowiak A.H., 2015, Rola Japonii w regionie Azji i Pacyfiku - zmiany i konsekwencje japońskiej pomocy rozwojowej, [w:] Ekonomia XXI Wieku, 2 (6)2015, Wydawnictwo Uniwersytetu Ekonomicznego we Wrocławiu, Wrocław.

JETRO, Japanese Trade and Investment Statistics, http:/www.jetro.go.jp/en/reports/statistics/.

Okamato J., 1997, Asian Regionalism and Japan, IDE APEC Study Center, Working Papers Series 96/97 - no. 2.

Statistical Handbook of Japan 2006, Statistics Bureau \& Statistical Research and Training Institute, Ministry of International Affairs and Communication, www.stat.go.jp.

Tanaka H., Liff A.P., 2009, Japan's Foreign Policy and East Asian Regionalism, International Institutions and Global Governance Program Japan Studies Program.

Yoshida T., 2004, East Asian Regionalism and Japan, IDE APEC Study Center, Working Papers Series 03/04 - no. 9 . 